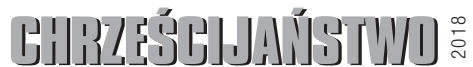 \\ SUILITPDIITHA
}

ZESZYTY SPOŁECZNEJ MYŚLI KOŚCIOŁA

\author{
Marek Safjan
}

\section{Społeczeństwo obywatelskie \\ w czasach kryzysu}

\section{Civil Society In Times of Crisis}

\begin{abstract}
Abstrakt: Artykuł przedstawia rozważania autora dotyczące społeczeństwa obywatelskiego. Autor omawia genezę idei społeczeństwa obywatelskiego, ściśle związanego z koncepcją popperowską społeczeństwa otwartego (open society), a następnie przedstawia zależność pomiędzy społeczeństwem obywatelskim i wpływem, jakie ma na nie system demokratyczny, aby w efekcie określić wzajemne relacje pomiędzy nimi. Jako metodę badawczą autor przyjął analizę tzw. czynników blokujących sprawne funkcjonowanie społeczeństwa obywatelskiego, w zależności od relacji z określonym systemem społecznym, ustrojowym bądź też ponadnarodowym.
\end{abstract}

Słowa kluczowe: Społeczeństwo obywatelskie, open society, Karl Popper, demokracja, społeczeństwo dialogu, państwo prawa, system instytucjonalny

Abstract: The article presents the Author's reflections regarding civil society. The Author discusses the origin of the idea of civil society, closely linked to Popper's concept of open society, and then presents the correlation between civil society and the influence the democratic system has on it in order to determine the relations between them. As a research method, the Author uses analysis of so-called impediments to the efficient functioning of civil society, depending on the relation with a particular social, political or supranational system.

Key words: Civil society, open society, Karl Popper, democracy, society of dialogue, state of law, institutional system

\section{Społeczeństwo obywatelskie, jako warunek istnienia demokracji}

Stoimy dzisiaj często wobec pytania o to, jakie są powody, które sprawiają, że systemy demokratyczne o silnych gwarancjach zapewniających, jak można by sądzić, dobre i sprawne funkcjonowanie państwa prawa okazują się w praktyce mocno niedoskonałe, wywołują rozczarowanie i obawy o przyszłość. Jedna z hipotez zawiera się w twierdzeniu, że formalne ustanowienie mechanizmów 
demokratycznego państwa prawa na poziomie konstytucyjnym i całego systemu prawnego nie jest jeszcze wystarczającym zabezpieczeniem przed kryzysem lub przed deformacjami, które dzisiaj możemy zaobserwować w niektórych państwach europejskich, w tym w Polsce. Przedstawione w artykule refleksje są próbą odpowiedzi na pytanie, jakie są zależności pomiędzy funkcjonowaniem demokracji a strukturami społeczeństwa obywatelskiego.

Idea społeczeństwa obywatelskiego pozostaje w ścisłym związku z koncepcją Popperowską społeczeństwa otwartego (open society). Społeczeństwo otwarte zakłada z istoty swej współuczestnictwo i kooperację wolnych obywateli, istnienie przestrzeni tolerancji, wolności i odpowiedzialności, w której jest miejsce na różnorodne formy kooperacji obywateli i realizacje różnych, często zasadniczo odmiennych koncepcji i stylów życia. Jest ta koncepcja całkowicie przeciwstawna idei społeczeństwa zamkniętego (closed society), które jest pozbawione instrumentów (a z reguły i możliwości) kierowania samym sobą [Popper 1986: 167]. Jak pisał Karl Popper: „Społeczeństwo zamknięte wyraża własne kredo według którego plemię/ród jest wszystkim, a jednostka niczym”, podczas gdy społeczeństwo otwarte powstaje wtedy, gdy ,jednostkowa inicjatywa i samodzielność działania stają się faktem. Interes jednostki jako jednostki, a nie jako plemiennego bohatera lub zbawcy staje się pierwszorzędny" [tamże; tłum. M. S.]. Idea społeczeństwa zamkniętego pozostaje $\mathrm{w}$ sprzeczności $\mathrm{z}$ ukształtowanymi w chrześcijaństwie zasadami życia społecznego, solidarności, pomocniczości i dobra wspólnego. Jak zauważa trafnie Jan Grosfeld wynika z nich: „(...) poszanowanie wolności i autonomii drugiego, ograniczenie dążenia do własnego dobra, tak by nie kolidowało ono z dobrem innej osoby. Jest rzeczą charakterystyczną dla chrześcijaństwa, że na pierwszym miejscu bez względu na okoliczności - stawia ono pojedynczą osobę z jej wolnością, a dopiero na drugim wspólnotę, społeczność, grupę. Wszelkie izmy jak nacjonalizm, faszyzm, komunizm, fundamentalizm, czynią odwrotnie, głosząc pierwszeństwo zbiorowości, z którą się utożsamiają podporządkowując jednostkę celom i interesom grupy" [Grosfeld 2016: 120].

O koncepcji Popperowskiej pisał słusznie inny autor Ludwig Kramer [Kramer 2013: 463-474]: „W zamkniętym społeczeństwie niektóre części grupy (kapłani, przywódcy, kościoły, klasy takie jak szlachetnie urodzeni itd.) przypisują sobie wiedzę, co jest dobre, a co złe. Otaczają wiedzę magicznymi atrybutami, aby ukryć wiedzę przed większością ludzkości. Decyzje podejmowane są tylko przez członków grupy, którzy „posiadają” prawdę, a krytyka tych decyzji nie jest akceptowana" [tłum. M. S.]. 
Charakterystyczne dla społeczeństwa obywatelskiego jest położenie nacisku na autonomię (samostanowienie jednostek), wolność i brak apriorycznej, jedynie słusznej, narzuconej z zewnątrz, prawdy opisującej rzeczywistość. Społeczeństwo otwarte wyklucza istnienie niemożliwych do zakwestionowania autorytetów, dysponujących nieograniczoną władzą decydowania o tym, co jest złem, a co jest dobrem dla społeczeństwa jako całości i dla poszczególnych jego członków. W społeczeństwie otwartym koniecznym składnikiem struktur, w ramach których ono funkcjonuje, są zróżnicowane formy organizacji obywatelskich, które albo kooperują z władzą publiczną, albo działają całkowicie samodzielnie w pewnych dziedzinach. Innymi słowy, społeczeństwo otwarte zakłada samoorganizację obywateli i zarazem ich odpowiedzialność za to, co się dzieje w wymiarze publicznym, wykraczającym poza ich własny krąg spraw.

Nakaz bycia odpowiedzialnym albo dzielenia się odpowiedzialnością współgra wyraźnie z myślą Jana Pawła II, który kładł silny akcent na sposób (powinność?) realizacji własnego ,ja” poprzez współdziałanie z innymi na rzecz dobra wspólnego. Bez współodpowiedzialności za los innych i uczestnictwa w przestrzeni publicznej nie jest możliwe funkcjonowanie prawdziwej demokracji: „Autentyczna demokracja jest możliwa tylko w państwie prawnym i w oparciu o poprawną koncepcję osoby ludzkiej. Wymaga ona spełnienia koniecznych warunków, jakich wymaga promocja zarówno poszczególnych osób, przez wychowanie i formację w duchu prawdziwych ideałów, jak i „podmiotowości” społeczeństwa, przez tworzenie struktur uczestnictwa i współodpowiedzialności" [Jan Paweł II 1991: 46; Balcerczyk 2016].

Społeczeństwa środkowej i wschodniej części Europy stoją wobec szczególnie poważnych wyzwań, ponieważ sama idea społeczeństwa obywatelskiego ma stosunkowo słabe zakorzenienie w świadomości obywateli, ze względu na zaszłości historyczne, a zwłaszcza ze względu na kilkadziesiąt lat egzystencji w reżimie komunistycznym. Wszelkie postacie autorytaryzmu sprawiają, że funkcjonowanie samodzielnych, swobodnie powstających struktur społecznych podlega istotnemu zablokowaniu. Według przytoczonej wyżej klasyfikacji Karla Poppera takie społeczeństwa mają charakter wybitnie „zamknięty”, wszelkie cechy identyfikujące taką organizację społeczeństwa są doskonale opisane, ale przede wszystkim dwa elementy wysuwały się na pierwszy plan.

Po pierwsze, jest to pełna kontrola nad wszelkimi przejawami aktywności społecznej (nawet tej niepozostającej w jakimkolwiek związku z działalnością 
polityczną). Po drugie jest to ideologia „jednej prawdy”, która oznacza nie tylko kontrolę nad komunikacją publiczną i brak swobodnego obiegu informacji, ale także zmonopolizowanie wszelkiego dyskursu publicznego i niedopuszczalność alternatywy wobec oficjalnie akceptowanego modelu życia publicznego. Taka koncepcja życia w społeczeństwie ubezwłasnowolnionym musiała prowadzić do deformacji świadomości obywatelskiej na wielu jej poziomach, przejawiającej się przede wszystkim w braku odpowiedzialności zarówno za los własny, za ukształtowanie własnego życia i realizację własnych aspiracji, jak i za funkcjonowanie społeczeństwa, jako takiego, a więc za to wszystko, co dzieje się w przestrzeni publicznej. Postawa „nie mam na nic wpływu, a wobec tego nie ma żadnego powodu, aby robić coś więcej niż wynika to z konieczności dostosowania się do rzeczywistości" zawiera w sobie mentalność społeczeństwa złożonego z obywateli będących „homo sovieticus” [Kołakowski 1989: 867; Tischner 1992]. Paradoksalnie, pomimo upływu 30 lat od upadku komunizmu sytuacja nie ulega zmianie. Kilkanaście lat temu pisałem, że „pasywność obywatelska drążąca jakość naszego życia publicznego jest przede wszystkim wynikiem braku odpowiedzialności obywatelskiej. Wolność, z której korzystamy i z której chcemy skorzystać w przyszłości jest także i dzisiaj, równie silnie uwarunkowana odpowiedzialnością obywatelską, której perspektywa musi wykraczać poza sferę własnej rodziny, kręgu znajomych i własnej aktywności zarobkowej" [Safjan 2007: 35]. Do takiej diagnozy warto dołączyć drugi element, związany ze społeczną pasywnością i brakiem odpowiedzialności za własne życie, a mianowicie „roszczeniowość” - „jeżeli to nie ja decyduję, to oczekuję, że Państwo samo zaspokoi moje potrzeby", który dobrze identyfikuje Wiktor Osiatyński wiążąc tę postawę z tradycyjnym myśleniem polskiego społeczeństwa o wszechmocy państwa. Otwartość społeczeństwa jest warunkiem tworzenia społeczeństwa obywatelskiego, ale nie jest to warunek wystarczający. Polskie społeczeństwo zachowywało nawet w czasach komunizmu w znaczącym stopniu cechy społeczeństwa otwartego, zdolnego mówić własnym głosem i zdolnego do ostrego sprzeciwu wobec autorytarnej władzy. Jednocześnie jednak - społeczeństwo - poza okresami zrywu - nie potrafiło budować trwałych struktur społeczeństwa obywatelskiego, zdolnego do współdziałania i współodpowiedzialności za innych [Grosfeld 2016: 131] ${ }^{1}$.

${ }^{1}$ Być może wynikało to, jak zauważa Jan Grosfeld ze zbyt słabo rozwiniętej skłonności do „współbycia” z drugim człowiekiem, która „oznacza gotowość do poświęcenia własnego dobra na rzecz drugiej osoby lub osób. «Uobywatelnienie» i «uspołecznienie» nie muszą oznaczać «uwspólnotowienia» relacji międzyludzkich". 
Pomiędzy społeczeństwem otwartym, społeczeństwem obywatelskim a demokracją istnieje więc nie bez przypadku ścisła zależność [Balcerczyk 2016: $111]^{2}$. Nie bez powodu, konsekwencje wynikające ze słabości społeczeństwa obywatelskiego bardzo wyraźnie pojawiły się wraz z upadkiem komunizmu, kiedy relatywnie mała liczba obywateli włączyła się do tworzenia nowego demokratycznego społeczeństwa. Deficyt w strukturach społeczeństwa obywatelskiego przekładał się na deficyt demokracji, powodując jej kruchość i niestabilność. Nie rozumiano zależności pomiędzy zaangażowaniem obywateli a jakością demokracji, a samo obalenie komunizmu miało prowadzić automatycznie do rozwiązania wszystkich problemów. W efekcie nawet partycypacja społeczeństwa w pierwszych wolnych wyborach w 1989 r. przyciągnęła rozczarowująco niski odsetek osób (wystarczy zauważyć, że w drugiej turze wyborów czerwcowych wzięło udział znacznie poniżej 50\% uprawnionych do głosowania). Znaczące są też dane statystyczne ilustrujące poziom bierności społeczeństwa w fazie schyłkowej komunizmu i na początku procesu transformacji" [Sasinowski 2012: 36] .

Zwraca się również uwagę na to, że Polska pozostawała na ostatnim miejscu wśród krajów europejskich pod względem aktywności wolontariackiej. Według badania Eurobarometru z 2011 r. średnio 24\% obywateli prowadzi działalność wolontariacką, z tej liczby 11\% w sposób systematyczny. Różnice między państwami członkowskimi pod względem zaangażowania w wolontariat są znaczące. Jak piszą autorzy badania: „Zaangażowanie $\mathrm{w}$ wolontariat jest bardzo rozpowszechnione w Holandii, gdzie ponad połowa respondentów uczestniczy w działalności wolontariackiej (57\%), z czego 31\% regularnie (...). Z kolei znacznie poniżej średniej UE znajdują się Malta (16\%), Hiszpania (15\%), Grecja (14\%), Rumunia 14\%, Bułgaria 12\% i Polska 9\% [Krasnowolski 2014: 26] ${ }^{4}$.

${ }^{2}$ Bardzo jasno wywodzi tę zależność na tle koncepcji demokracji u V. Havla, przypominając m.in. twierdzenie Havla o tym, że podstawą demokracji jest społeczeństwo obywatelskie.

${ }^{3}$ W 1982 roku 53\% badanych uważało, że nie istnieją w Polsce takie organizacje i stowarzyszenia, które działałyby w ich interesie. W 1991 r. tylko 1,1\% badanych deklarowało przynależność do partii politycznych, $3 \%$ postrzegało partie polityczne, jako organizacje reprezentujące ich interesy, $7 \%$ badanych deklarowało potrzebę osobistego uczestnictwa w rządzeniu, $87 \%$ badanych wolałoby być dobrze rządzonymi.

${ }_{4}$ Zob. opracowanie Eurobarometr 75.2, Wolontariat, badanie http://www.europarl.europa. eu/pdf/eurobarometre/2011/juillet/04_07/SA_en.pdf przeprowadzone przez TNS Opinion na wniosek Parlamentu Europejskiego 2011 r., s. 20; niestety brak jest nowszych danych, ale wydaje się, że od tamtego czasu sytuacja nie zmieniła się w sposób zasadniczy. 


\section{Cechy współczesnego społeczeństwa obywatelskiego}

Nie istnieje w naukach społecznych jednolita definicja społeczeństwa obywatelskiego, brak jest też normatywnego określenia cech takiego społeczeństwa, pomimo tego, że niejednokrotnie $\mathrm{w}$ aktach najwyższej rangi (konstytucja, traktaty europejskie) znajdujemy wyraźne, bezpośrednie odniesienia do tego pojęcia. Jest jednak charakterystyczne, że najczęściej w ujęciach teoretycznych nacisk jest położony na cechę, jaką jest partycypacja wolnych, świadomych i odpowiedzialnych obywateli w kształtowaniu zasad, według których funkcjonuje współczesne społeczeństwo. Ideę partycypacji najpełniej wyrażał w swych pracach Jurgen Habermas, podkreślając wagę otwartego dyskursu publicznego, którego partnerzy posługują się racjonalnymi argumentami i są skłonni zaakceptować przeciwstawne racje drugiej strony, i ostatecznie kształtować proces decyzyjny na podstawie wyniku takiej publicznej debaty. Jak podkreśla się w literaturze, owa partycypacyjność i delibaratywność społeczeństwa otwartego stanowi pewien stan idealny ideal speech situation [Cammaerts 2006: 177], a więc jest to postulat-model, do którego należy dążyć. Wskazane wyżej cechy - partycypacyjność i deliberatywność - same przez się nie opisują jeszcze tego, jak organizuje się społeczeństwo otwarte, innymi słowy, jak osiągać czy dążyć do takiego stanu idealnego. Jest jednak jasne, że warunkiem, konieczną przesłanką jest istnienie społeczeństwa obywatelskiego, a więc istnienie takich struktur i organizacji obywateli, które mogą efektywnie wpływać na procesy rządzenia państwem w różnych sferach jego funkcjonowania - począwszy od tworzenia prawa poprzez funkcjonowanie administracji, podejmowanie decyzji przez organy władzy publicznej, a także uczestnictwo w samorządności lokalnej. Trafnie więc opisuje konieczny wpływ społeczeństwa na funkcjonowanie struktur państwa Ludwig Kramer: „Koncepcja społeczeństwa otwartego zaczyna się od uznania, że ani nauka, ani prawa stworzone przez człowieka nie mogą zawierać absolutnej prawdy, ponieważ nikt nie może przewidzieć przyszłości z pewnością. Decydenci polityczni - w szczególności ustawodawcy - powinni uczyć się z nauk przyrodniczych, że postęp można osiągnąć jedynie metodą prób i błędów: tam, gdzie ustawodawstwo okazuje się skuteczne, należy je kontynuować, w przeciwnym razie należy je ulepszyć. Ponieważ nie ma monopolu na prawdę, konieczne jest, aby ustawy i decyzje polityczne były dyskutowane publicznie, krytykowane i poddawane szerokim rozważaniom na temat ich zalet i wad. W konsekwencji obywatele muszą rozwijać krytyczne myślenie; jednak oznacza to przyzwolenie na publiczne omawianie ustaw i decyzji. W związku z tym, administracja otwartego społeczeństwa musi się otworzyć, być przychylną i promować dialog ze społeczeństwem obywatelskim starać się w miarę możliwości propagować publiczną 
dyskusję. Im bardziej dyskusje na temat prawa i polityki w społeczeństwie są otwarte, krytyczne i kontrowersyjne oraz odbywają się przy udziale obywateli, tym bardziej, to społeczeństwo można uznać za «społeczeństwo otwarte»" [Kramer 2013: 463-474; tłum. M. S.].

Idealnie współbrzmią z tymi refleksjami słowa Józefa Tischnera, który wskazywał że „alternatywą dla społeczeństwa monologu jest społeczeństwo dialogu” i dodawał: „(...) Ma swoją prawdę władza i ma swoją prawdę poddany, podobnie jak władza i poddani mają swoją iluzję. Nikt nie może przypisywać sobie monopolu na prawdę. Przekonanie to otwiera drogę do społeczeństwa dialogu” [Tischner 1992: 147].

Powtórzmy więc: bez wątpienia istnieje ścisła zależność pomiędzy pojęciami społeczeństwo otwarte, społeczeństwo obywatelskie system demokratyczny. Warto obecnie zatrzymać się na chwilę nad pytaniem, w jakim sensie i jak rozumiany system demokratyczny determinuje funkcjonowanie społeczeństwa obywatelskiego?

\section{Demokracja a społeczeństwo obywatelskie}

Władza, która ma charakter autorytarny, która monopolizuje prawo do podejmowania wszelkich decyzji związanych z funkcjonowaniem społeczeństwa, kontroluje wszelkie przejawy aktywności społecznej i sferę wolności ogranicza do tego, co jest wyraźnie dozwolone - nie stwarza przestrzeni koniecznej do rozwijania społeczeństwa obywatelskiego. To jest oczywiste - o czym była już mowa - doświadczenie społeczeństw postkomunistycznych w naszej części Europy. Społeczeństwo obywatelskie ma sens jedynie wtedy, kiedy istnieją instytucjonalne, formalne gwarancje, które umożliwiają oddziaływanie na to, w jaki sposób będą działały mechanizmy życia publicznego. A oto kilka przykładów.

Zaangażowanie organizacji obywatelskich w proces mobilizowania społeczeństwa do uczestnictwa w procesach wyborczych ma sens jedynie wtedy, kiedy istnieją wolne wybory. Tworzenie wizji rozwiązania tych lub innych ważnych lub nawet mniej ważnych problemów życia społecznego przez NGO-sy (organizacje pozarządowe) ma sens jedynie wtedy, kiedy taka wizja (program lub propozycja) będzie realnie wzięta pod uwagę $\mathrm{w}$ demokratycznym procesie podejmowania decyzji, w tym przede wszystkim w procedurach uchwalania prawa. Racjonalna debata publiczna, nieskrępowana istnieniem jedynie słusznej prawdy i niemonopolizowana przez namaszczane przez władze autorytety - może toczyć się pod warunkiem, że istnieją gwarancje wolności wypowiedzi. Mobilizowanie ludzi do demonstrowania publicznie swoich poglądów, dążeń i oczekiwań ma sens jedynie 
wtedy, kiedy prawo podstawowe do wolności zgromadzeń nie podlega arbitralnym ograniczeniom ze strony władzy etc. Mają więc rację ci, którzy czynią konieczne iunctim pomiędzy funkcjonowaniem społeczeństwa obywatelskiego a istotnymi składnikami instytucjonalnymi systemu demokracji liberalnej. Henryk Sasinowski definiuje np. społeczeństwo obywatelskie w sposób następujący:

„(..) - suwerenem jest naród sprawujący władzę przez swoich przedstawicieli,

- władza działa na podstawie stanowionego prawa,

- istnieje prawny system ochrony praw i wolności obywateli,

- funkcjonują instytucje gwarantujące przestrzeganie praw,

- jest zagwarantowane uczestnictwo obywateli w życiu społecznym"

[Sasinowski 2012: 33].

Takie ujęcie jest jednak niepełne i może w konsekwencji prowadzić do nieuzasadnionego utożsamienia formalnych cech i gwarancji systemu demokratycznego z funkcjonowaniem społeczeństwa obywatelskiego. Tymczasem jest to warunek konieczny, ale nie wystarczający. W przeciwnym wypadku stwarzamy iluzję, która może tworzyć nadmierne oczekiwania i rozczarowania. Słusznie bowiem podkreślał Bart Cammaerts: „Debata i uczestnictwo są wyraźnie zakwestionowanymi pojęciami, dlatego ważne jest, aby lokalne rady, rządy i organizacje międzynarodowe w jasny sposób określały, z czym wiąże się uczestnictwo w procesach politycznych, jakie uprawnienia mają obywatele, które mogłyby wpłynąć na wyniki oraz w jaki sposób zaangażowanie obywatelskie w procesy polityczne przez (zorganizowanych) obywateli wiąże się z systemem przedstawicielskim. Jeśli tak nie jest, mogą wzrosnąć błędne oczekiwania, często powodując jeszcze więcej frustracji i mniej zaangażowania" (tłum. M. S.) [Cammaerts 2006: 177; tłum. M. S.].

Społeczeństwo obywatelskie może działać jedynie wtedy, kiedy formalne gwarancje systemu demokratycznego działają w sposób efektywny, a nie są pozorem, a jednocześnie towarzyszą im odpowiednia tradycja i utrwalony obyczaj demokratyczny oraz mocne przekonanie członków społeczności o istnieniu wspólnej odpowiedzialności za sferę publiczną. Demokratyczna legitymacja systemu i jego reprezentatywność nie są cechami, które mogą zapewnić same przez się aktywność i rozwój społeczeństwa obywatelskiego. Jak wskazują, bowiem liczne przykłady o charakterze historycznym (i nie tylko historycznym), systemy wspierające się na demokratycznie wyrażonej woli suwerena ulegać mogą niekiedy istotnej deformacji prowadzącej się do wytworzenia systemu, który coraz częściej jest określany mianem „demokracji nie-liberalnej”, w którym aktywność obywatelska ulega 
ograniczeniu. Pomińmy w tym miejscu kwestię, na ile sama koncepcja „demokracji nieliberalnej” nie tworzy oksymoronu i spróbujmy zająć się wyjaśnieniem, skąd mogą wynikać czynniki blokujące funkcjonowanie społeczeństwa obywatelskiego.

\section{O blokadach „społeczeństwa obywatelskiego”}

\section{Kategorie czynników blokujących}

Czynniki potencjalnie blokujące funkcjonowanie społeczeństwa obywatelskiego są mocno zróżnicowane i mogą oddziaływać w niejednorodnym stopniu w zależności od konkretnego społeczeństwa. Wyróżnia się wśród nich przyczyny o charakterze zewnętrznym, jak i te, które są wytworem samego społeczeństwa obywatelskiego [Kurczewska, Staszyńska, Bajor 1993; Krasnowolski 2014]. Te pierwsze pojawiają się w relacjach pomiędzy państwem i jego strukturami (na szczeblu centralnym i lokalnym) i instytucjami a społeczeństwem, są rezultatem wadliwych rozwiązań formalnych albo - moim zdaniem - deformacji w sferze ich funkcjonowania, za którą odpowiedzialność ponoszą sprawujący władzę publiczną, mogą też wynikać ze słabości więzi lokalnych i atomizacji wspólnot, a więc według określenia cytowanego wyżej autorów słabości „prywatnych ojczyzn” [Kurczewska, Staszyńska, Bajor 1993; Krasnowolski 2014]. Te drugie wynikają z postaw samego społeczeństwa, są moim zdaniem w pierwszym rzędzie efektem braku tradycji „obywatelskości”, a w konsekwencji utrwalonego w pewnych grupach społecznych oportunizmu i konformizmu, bierności, słabo rozwiniętej świadomości obywatelskiej i niskiego poziomu edukacji. Według ww. autorów należą do tej kategorii „także oczekiwania bezpieczeństwa socjalnego i postawa roszczeniowa wobec państwa, żądanie funkcjonowania państwa opiekuńczego oraz skłonność do integracji negatywnej tj. integracji przeciw czemuś lub komuś, a nie integracji pozytywnej”. Wśród tych przyczyn wymienić można też te, które Jan Grosfeld identyfikuje jako brak „uwspólnotowienia” relacji międzyludzkich [Grosfeld 2016: 131].

\section{Przykłady blokad w społeczeństwie demokratycznym}

a) Blokady instytucjonalne. Mit reprezentatywności - władza większości parlamentarnej

Jedną z najczęściej doświadczanych blokad społeczeństwa obywatelskiego jest deformacja systemu demokratycznego polegająca na sprowadzaniu relacji władza - społeczeństwo do prymitywnej tezy, że demokratycznie wybrana większość parlamentarna dysponuje dostateczną legitymacją „reprezentatywności”, która umocowuje ją do rozstrzygania o wszystkich sprawach dotyczących społeczeństwa w sposób samodzielny, bez potrzeby konsultacji, komunikacji, dialogu z tymi środowiskami, 
które nie stanowią zaplecza partii sprawującej władzę. Prawda jest - w takim ujęciu - zawsze po stronie tych, którzy mogą skutecznie poprzez głosowanie większościowe narzucić swoją wolę w parlamencie i przyoblec ją w postać obowiązującego prawa. Większość określa w sposób kategoryczny i wyłączny, jak rozumieć prawo oraz wartości i cele, które ma ono wyrażać i zakłada z natury rzeczy, że nie jest ograniczona przez żadne inne bariery, w tym przez prawo najwyższej rangi (konstytucja), bo wola narodu (reprezentowana przez większość) sytuuje się ponad tak rozumianym prawem. W takiej „konstelacji ideologicznej” nie istnieje już oczywiście przestrzeń na działania organizacji społeczeństwa obywatelskiego - stają się one zbędne, bo deformacja reprezentatywności działa niczym brzytwa Ockhama w stosunku do wszystkich kategorii interesów o charakterze mniejszościowym. Istotna cecha społeczeństwa obywatelskiego, jaką jest pluralizm i ścieranie się różnorodnych interesów znika w ten sposób z pola widzenia po to, aby zamienić się w swoje przeciwieństwo dyktat jednego obdarzonego monopolem mówienia prawdy środowiska politycznego. Następuje powrót do zasady znanej z czasów komunistycznych: „jeden naród, jedna partia". W społeczeństwie, w którym dominuje jedna słuszna narracja polityczna na temat rzeczywistości, proces tworzenia prawa przekształca się w proces instrumentalizacji prawa, które musi spełniać określone założenia ideologiczne i służyć nie tyle dobru wspólnoty obywatelskiej, jako takiej, ale osiąganiu celów służących jednej partii. W stosunku do okresu komunistycznego istnieje jedna tylko, choć ważna nadal różnica, że rządzący uzyskali legitymacje do rządzenia w drodze demokratycznie przeprowadzonych wyborów. W takiej konstelacji politycznej odpada jednak zasadniczy motyw dla tworzenia inicjatyw i angażowania społeczeństwa obywatelskiego do jakichkolwiek działań zmierzających do zmiany i poprawienia systemu prawnego, ponieważ wszystkie takie inicjatywy zostaną odrzucone i pozostawione bez realnego wpływu na przebieg procesu legislacyjnego. Znika naturalna tendencja systemu demokratycznego do poszukiwania kompromisu, słuchania drugiej strony, pojawia się w to miejsce apatia i zniechęcenie do działań prospołecznych. Zanika deliberatywny charakter demokracji - habermasowska przesłanka otwartego społeczeństwa, w której poszukiwanie rozwiązań zgodnych z dobrem ogółu następuje poprzez ścieranie się racji i argumentów.

\section{b) naruszenie zasad państwa prawa}

W społeczeństwie, które przestaje respektować fundamentalne założenia, na których opiera się państwo prawa (zasady podziału i wzajemnego hamowania się władz, poszanowanie wolności obywatelskich oraz samorządności) musi następować proces upadku open society, a w konsekwencji destrukcja społeczeństwa obywatelskiego. W społeczeństwie otwartym, prawo - jak stwierdziliśmy wyżej - ma tworzyć ramy, 
w których wolni obywatele, za pośrednictwem swych swobodnie powstających i funkcjonujących organizacji, są współpartnerami procesu rządzenia. Jeżeli prawo staje się nieprzewidywalne i znika jego hierarchiczna struktura, zapewniająca realne poszanowanie gwarancji konstytucyjnych praw i wolności zawartych w konstytucji, przestaje być ono środkiem wolności, a staje się przede wszystkim środkiem opresji. Tymczasem demokratycznie wybrana większość powinna zawsze kierować się imperatywem nadrzędności słynnej kelsenowskiej Grundnorm nad całym porządkiem prawnym [Kelsen 1967]. Jest to jedna z kluczowych przesłanek pozwalających na rozumienie współczesnej demokracji - i zarazem konieczny warunek open society. Taka lekcja płynie z doświadczeń historycznych, które jasno pokazywały deficyt i słabość klasycznego, prostego mechanizmu demokracji opartego wyłącznie na legitymacji wyborczej. W systemie, w którym nie są szanowane zasady podziału władzy musi następować deformacja wynikająca przede wszystkim z braku hamulców dla „tyranii większości”, które w państwie prawa są usytuowane w niezależnym sądownictwie - od sądów konstytucyjnych i najwyższych począwszy na sądach powszechnych skończywszy. Sądy kontrolowane przez władzę wykonawczą nie mogą pełnić skutecznie swojej roli niezależnych arbitrów, a ich misją i powołaniem staje się ochrona interesów państwa, a nie obywateli5. Jeżeli nie jest przestrzegane prawo, nie mogą zadziałać skutecznie mechanizmy kontroli nad poczynaniami władzy, a więci írodki ochrony praw obywateli. Idea wyrażona w twierdzeniu, pozornie atrakcyjnym „słuszność ponad prawem" - prowadzi w istocie rzeczy do zakwestionowania rządów prawa jako takich. W państwie, w którym już nie działają mechanizmy podziału władzy dochodzi, co więcej do paradoksalnego zjawiska wzajemnego zwalczania się poszczególnych segmentów władzy (takie zjawisko można było obserwować w maju 2018 r. w związku z prezentacja przed Komisją Europejską tzw. Białej Księgi, w której szef rządu Rzeczypospolitej przedstawiał swoje fundamentalne zarzuty wobec wymiaru sprawiedliwości, oskarżając cały stan sędziowski o tolerowanie patologii i korupcji).

Obok wolności zrzeszania się w społeczeństwie obywatelskim kluczową rolę odgrywają wolność słowa oraz wolność zgromadzeń. Ta pierwsza (wolność wypowiedzi, innymi słowy, wolność komunikacji publicznej) jest mocno zdeformowana, w społeczeństwie opartym na „tyranii większości” - jeżeli dochodzi do monopolizacji mediów publicznych i zablokowania ich roli, jako obiektywnego forum wymiany informacji, poglądów i stanowisk nie może się już rozwijać rzeczywista debata publiczna. Swobodny i racjonalny dyskurs publiczny przekształca się w kanał propagandowy jednej (jedynie

5 Taki postulat wyrażony wprost w artykule wiceprezesa TK Muszyńskiego w „Rzeczpospolitej” z 22.03.2018 r. 
słusznej opcji politycznej), a ci, którzy są jej przeciwnikami z interlokutorów stają się wrogami. Swoboda wypowiedzi ulega niebezpiecznemu zawężeniu, jeśli przedstawiciele społeczeństwa - wolni obywatele mogą podlegać odpowiedzialności karnej za wygłaszanie poglądów niezgodnych z oficjalną narracją polityczną, historyczną czy ideologiczną. Ustawy, które usiłują narzucić jedyną wizję historii muszą mieć efekt mrożący dla rozwoju debaty w społeczeństwie, które może rozwijać się efektywnie jedynie poprzez autorefleksję i swobodną krytykę, w tym odnoszącą się do własnej historii, własnych błędów, własnych słabości i niedostatków.

Niebezpieczna dla funkcjonowania wolnej przestrzeni obywatelskiej jest tendencja do ograniczenia wolności zgromadzeń, która ma fundamentalne znaczenie dla społeczeństwa obywatelskiego. Jeżeli wolność zgromadzeń przekształca się $\mathrm{w}$ silnie reglamentowane prawo do zgromadzeń, to $\mathrm{w}$ takim wypadku musi zapalać się czerwone światło ostrzegawcze. Jeżeli następuje hierarchizacja prawa do zgromadzeń - i okazuje się, że niektóre są ważniejsze, a niektóre mniej ważne $\mathrm{i}$ „mniej legalne”, to znaczy że mamy do czynienia z poważną ingerencją władzy publicznej w wolność społeczeństwa obywatelskiego.

Jeżeli demonstracje i protesty uliczne - i do tego mocno reglamentowane przekształcają się $\mathrm{w}$ jedyną formę uczestnictwa obywateli w procesie rządzenia państwem i realnego oddziaływania na stan spraw publicznych, to z całą pewnością dochodzi do deformacji form działania społeczeństwa obywatelskiego. Masowe demonstracje, strajki i protesty w Polsce w ostatnim okresie funkcjonowania systemu komunistycznego z całą pewnością nie były przejawem funkcjonowania społeczeństwa obywatelskiego, ale aktem determinacji społeczeństwa, które dopiero walczy o przywrócenie mechanizmów demokratycznych, zapewniających realny udział we współrządzeniu państwem. Trzeba stwierdzić, w konsekwencji, że obecne w Polsce protesty, manifestacje w obronie praw i wolności, przywrócenia podstawowych demokratycznych zasad i mechanizmów (w obronie konstytucji i trybunału konstytucyjnego, w obronie niezależnych sądów, wolności zgromadzeń etc.) nie mogą być kwalifikowane, jako wyraz swoistej ekspresji społeczeństwa obywatelskiego, ale raczej jako przejaw zaangażowania obywateli w walkę o to, by takie społeczeństwo mogło się w przyszłości swobodnie rozwijać.

Samorządność, decentralizacja i dekoncentracja, warunki rozwijania społeczeństwa obywatelskiego na poziomie lokalnym, mogą być realizowane wtedy, kiedy przestrzegana jest w ramach państwa prawa konstytucyjna zasada pomocniczości. $\mathrm{W}$ ostatnich latach pojawiają się na tym tle istotne bariery a diagnoza postawiona 
przed ponad 10 laty przez profesorów Barbarę Imiołczyk i Jerzego Regulskiego w ramach raportu Konwersatorium „Doświadczenie i przyszłość” pozostaje w pełni aktualne [Imiołczyk, Regulski 2007: 8-9] ${ }^{6}$.

Konkludując w tym miejscu uwagi na temat barier instytucjonalnych należy zauważyć, że w przestrzeni państwa, w którym zaczyna funkcjonować mit reprezentatywności władzy oraz ulegają deformacji mechanizmy społeczeństwa demokratycznego organizacje i instytucje społeczeństwa obywatelskiego przestają być partnerem pełniącym funkcje komplementarne - wobec władzy, a stają się strukturą alternatywną - ustawiając się w opozycji wobec władzy.

W konsekwencji - instytucje społeczeństwa obywatelskiego, które są powołane do pełnienia funkcji komplementarnych wobec organów publicznych ulegają marginalizacji. Władza nie ma potrzeby czerpania z zasobów społeczeństwa obywatelskiego, ponieważ jako mająca wystarczającą legitymację dzięki swojej reprezentatywności dysponuje prawem do podejmowania wszelkich decyzji w imieniu i za społeczeństwo.

\section{c) blokady świadomościowe}

Bariery dla tworzenia i skutecznego funkcjonowania społeczeństwa obywatelskiego wynikają też z przyczyn wewnętrznych, leżących po stronie członków danej społeczności, a które działają niezależnie od otoczenia instytucjonalnego. Jest to teza szczególnie aktualna w odniesieniu do dużej części społeczeństw postkomunistycznych, o czym wspominaliśmy już wcześniej. Trafna jest refleksja Wiktora Osiatyńskiego, że dążenie do niepodległości i walka z władzą autorytarną przesłoniły inne cele, w tym tworzenie silnego społeczeństwa obywatelskiego [Osiatyński 2004: 119]. Dzisiaj zjawisko nasilających się postaw ksenofobicznych, zamykania się na wartości europejskie w tym na solidarność (co ujawnia się w przypadku uchodźców) sprzeciw wobec wszelkich inności i zanik tolerancji mają charakter szerszy, nie jest on bowiem ograniczony do jednego tylko społeczeństwa europejskiego. W społeczeństwach postkomunistycznych utrwala się postawa bierności i konformizmu wobec zachowań władzy. W Polsce antyliberalne, odwracające proces transformacji ustrojowej ustawodawstwo zmieniające dramatycznie system kontroli konstytucyjności prawa, a także cały system wymiaru sprawiedliwości, zderza się dzisiaj z dość pasywną postawą społeczeństwa, w tym także środowisk

\footnotetext{
${ }^{6}$ Autorzy pisali m.in. że naruszenie zasady pomocniczości i powtórnej centralizacji nasilają się, co powoduje m.in. spadek zaufania społecznego do władz.
} 
wydawałoby się najbardziej świadomych zagrożeń dla procesu demokratycznego, jakimi są środowiska prawnicze. Jako obywatele - bierni, odmawiający zaangażowania w zachodzące procesy w społeczeństwie stajemy się sami odpowiedzialni za rezultat negatywny tych procesów. Zgodzić się należy z V. Havlem: „Człowiek nie musi aprobować kłamstwa. Wystarcza, że zaaprobował życie z nim i w nim. Już przez to samo, bowiem zatwierdził system, realizuje go, robi, jest nim" [Havel 2011: 44].

\section{Wymiar europejski społeczeństwa obywatelskiego}

We współczesnej Europie o funkcjonowaniu społeczeństwa obywatelskiego należy myśleć w kategoriach szerszych, wykraczających poza granice poszczególnych krajów, czy poza ramy zasady terytorialności. W zintegrowanej Europie musimy budować obywatelskie społeczeństwo europejskie. Każdy z nas powinien móc o sobie powiedzieć civis europeus sum. Przywiązanie Europejczyków do idei obywatelstwa europejskiego może stać się panaceum na „sklerotyczność” europejskich instytucji, ale tylko wtedy, kiedy będzie ono tworzyło podstawę do podejmowania wspólnych działań i zaangażowania na rzecz tego, co determinuje istotę europejskości, a mianowicie wspólnego systemu wartości. Do nich należy również europejska solidarność, która powinna być manifestowana nie tyle przez państwa i instytucje, ale przede wszystkim przez organizacje społeczeństwa obywatelskiego. Warto przypomnieć, jak istotną rolę odegrały i odgrywają do dzisiaj w Europie w związku z kryzysem humanitarnym spowodowanym masowym napływem uchodźców organizacje społeczeństwa obywatelskiego w szczególności w Niemczech, ale także w Austrii, Hiszpanii i we Włoszech - mocniej czujące odpowiedzialność za los uciekinierów $\mathrm{z}$ wojny syryjskiej niż formalne struktury instytucjonalne. Jeżeli jedną z istotnych przyczyn kryzysu europejskiego jest utrata porządku wartości, mająca związek z dystansowaniem się coraz większym Europy od swojego dziedzictwa chrześcijańskiego, to przywrócenie tego porządku, odwołanie się do swoistego „kodu europejskości”, jakim są wspólne wartości staje się coraz bardziej kwestią odpowiedzialności indywidualnej i zbiorowej obywateli Europy i nastąpić może jedynie przez autentyczne ożywienie struktur społeczeństwa obywatelskiego. Aktualna sytuacja naznaczona kryzysem samej idei integracji europejskiej, w momencie załamywania się podstawowych zasad, które konsty tuują fundament Europy, tworzy jednocześnie wyjątkową okazję ażeby udowodnić rzeczywiste znaczenie solidarności w UE, której wyrazem mogłoby być wzajemna współodpowiedzialność i kooperacja struktur społeczeństwa obywatelskiego. Jakże, więc słusznie stwierdza, E.-W. Böckenförde: „solidarność jest jednocześnie sposobem na wykazanie odpowiedzialności za drugiego w połączeniu z pozytywnym działaniem lub świadczeniami na rzecz innych, czy to ze strony jednostek, czy poszczególnych wspólnot czy społeczeństwa. 
Tak rozumiane pojęcie «my» lub mówiąc inaczej wspólnej «tożsamości» sprawia, że te sprawy, które dotykają innego dotyczą również mnie samego, intelektualnie i emocjonalnie i nie oddzielają się od mojej własnej egzystencji. Tworzy to podstawę - jako przejaw solidarności - do uznania współodpowiedzialności, wzajemnego wsparcia i współdziałania. Jest to zarazem «sens istnienia» w ujęciu lorda Dahrendorfa, świadomość i sens wspólnoty i woli tworzenia wspólnoty, należenia do niej i uczestniczenia w niej na dobre i na złe" [Böckenförde 2005].

Formalne warunki tworzenia skutecznego działania społeczeństwa obywatelskiego na poziomie europejskim istnieją. Traktat o Unii Europejskiej (art. 10 i 11) zawiera szeroką formułę dla funkcjonowania społeczeństwa obywatelskiego. Po raz pierwszy w historii integracji europejskiej określa się wprost demokracje partycypacyjną, jako model demokracji dla społeczeństwa europejskiego. Warto o tym pamiętać dzisiaj, kiedy frustracje w Europie adresowane są najczęściej do instytucji europejskich, ale całkowicie pomijana jest istotna przyczyna zapowiadanego zmierzchu europejskości, którą jest niedostatek autentycznego zaangażowania obywateli europejskich we wspólne działania, a w konsekwencji brak odpowiedzialności nas samych za własną przyszłość.

\section{Konkluzja}

Brakodpowiednich instytucji demokratycznych (ram formalno-prawnych) fundamentalnie osłabia społeczeństwo obywatelskie i odwrotnie: brak dostatecznie rozwiniętych struktur społeczeństwa obywatelskiego uniemożliwia skuteczne funkcjonowanie, a wręcz utrzymanie demokracji (zjawisko sprzężenia zwrotnego). W krajach Europy Środkowej (postkomunistycznych) pojawia się z całą wyrazistością ta druga zależność: w okresie transformacji zostały zbudowane silne ramy formalno-prawne dla funkcjonowania mechanizmów demokratycznych (zasada państwa prawnego, gwarancja praw podstawowych, silne formalne gwarancje niezależności sądów, wolność mediów i rozbudowany samorząd terytorialny), ale jednocześnie zapomniano o budowie społeczeństwa obywatelskiego, pomimo czysto werbalnych deklaracji na rzecz tej idei. Ten stan istnieje np. od zarania III RP (udział w najważniejszych historycznie wyborach w 1989 - niewiele ponad 60\%, druga tura niewiele ponad 25\% partycypacji uprawnionych do głosowania). Elity intelektualne i polityczne budowały państwo demokratyczne niejako „obok” społeczeństwa, które nie uczestniczyło w procesach tworzenia nowych instytucji i nie rozumiało ani celów, ani kierunku reform.

Dedykując ten krótki esej Profesorowi Janowi Grosfeldowi mam pełną świadomość niedostatków rozważań nad przyczynami słabości społeczeństwa obywatelskiego, 
które wynikają z tych sfer i obszarów naszej kultury, którymi Jubilat zajmuje się zwłaszcza w swej ciekawej rozprawie „Dlaczego chrześcijanie potrzebują Żydów?”. Mam jednak nadzieję, że te kilka refleksji, które przedstawiam zainspirują prof. Grosfelda do kontynuowania poszukiwań mających na celu odpowiedź, dlaczego identyfikowana przez niego zbieżność pomiędzy religijnością a uspołecznieniem wyznawców nie zapewnia dostatecznie silnych postaw i aktywności na rzecz społeczeństwa obywatelskiego. Multos annos drogi Janku!

\section{Bibliografia:}

Balcerczyk I. (2016), Społeczeństwo obywatelskie w myśli społecznej Jana Pawła II i Vaclava Havla, Wyd. Uniwersytetu Łódzkiego, Łódź.

Böckenförde E.-W. (2005), Conditions for European Solidarity, Central European University Press.

Cammaerts B. (2006), The Convention on the future of Europe: Civil society and the Use of the Internet in European Decision-making Process, European Integration, Tom 28, Numer 3.

Grosfeld J. (2016), Dlaczego chrześcijanie potrzebują Żydów, Wyd. Św. Wojciecha, Poznań. Havel V. (2011), Siła bezsilnych i inne eseje. Wybór tekstów Andrzej S. Jagodziński, Warszawa.

Imiołczyk B., Regulski J. (2007), Samorzadność i demokracja lokalna, Raport Konwersatorium Doświadczenia i Przyszłość, nr 2/2007, Warszawa, 11.2007 r.

Jan Paweł II (1991), Encyklika Centesimus annus (W setna rocznice encykliki Leona XII «Rerum novarum»), 1.05.1991.

Kelsen H. (1967), Pure Theory of Law, Berkely.

Kołakowski L. (1989), Główne nurty marksizmu, t. III, Rozkład, wyd. Krąg-Pokolenie.

Kramer L. (2013), The EU, access to environmental information and the open society, „RA Forum", grudzień 2013 r., tom 14, numer 4.

Krasnowolski A. (2014), Społeczeństwo obywatelskie i jego instytucje, Kancelaria Senatu, Biuro Analiz i Dokumentacji, Warszawa 2014, https://www.senat.gov.pl/gfx/senat/pl/ senatopracowania/58/plik/ot-_627_internet.pdf.

Kurczewska J., Staszyńska K., Bajor H. (1993), Blokady społeczeństwa obywatelskiego: czyli słabe społeczeństwo obywatelskie i słabe państwo, w: Rychard A., Fedorowicz M. (red.), Społeczeństwo w transformacji. Ekspertyzy i studia, Warszawa, Wyd. IFiS PAN. Osiatyński W. (2004), Rzeczpospolita obywateli, Warszawa.

Popper K. (1986), The Open Society and Its Enemies, vol. I, Londyn, Nowy York 1986.

Safjan M. (2007), Wyzwania dla Państwa Prawa, Wolters Kluwer, Warszawa.

Sasinowski H. (2012), Społeczeństwo obywatelskie i jego rola $w$ budowie demokracji, „Economy and Management” 1/2012.

Tischner J. (1992), Etyka solidarności, Kraków. 